\title{
Mechanical Processing of Hard Coal as a Source of Noise Pollution. Case Study in Poland
}

\author{
Witold Biały $^{1}{ }^{1}$, Łukasz Bołoz $^{2, *} \mathbb{(}$ and Jacek Sitko ${ }^{1}$ \\ 1 Department of Production Engineering, Faculty of Management and Organization, Silesian University of \\ Technology, Roosevelta 26, 44-800 Zabrze, Poland; witold.bialy@polsl.pl (W.B.); jsitko@polsl.pl (J.S.) \\ 2 Department of Machinery Engineering and Transport, Faculty of Mechanical Engineering and Robotics, AGH \\ University of Science and Technology, A. Mickiewicza Av. 30, 30-059 Krakow, Poland \\ * Correspondence: boloz@agh.edu.pl; Tel.: +48-12-617-3081
}

Citation: Biały, W.; Bołoz, Ł.; Sitko, J. Mechanical Processing of Hard Coal as a Source of Noise Pollution. Case Study in Poland. Energies 2021, 14, 1332. https://doi.org/10.3390/ en14051332

Academic Editor: Manoj Khandelwal

Received: 14 January 2021

Accepted: 24 February 2021

Published: 1 March 2021

Publisher's Note: MDPI stays neutral with regard to jurisdictional claims in published maps and institutional affiliations.

Copyright: (c) 2021 by the authors. Licensee MDPI, Basel, Switzerland. This article is an open access article distributed under the terms and conditions of the Creative Commons Attribution (CC BY) license (https:// creativecommons.org/licenses/by/ $4.0 /)$.

\begin{abstract}
This article presents the results of noise tests, measurements and proposals of solutions that have an impact for reducing noise at one of the Jastrzębska Spółka Wegglowa S.A. mines. All units and workstations at the mechanical coal processing plant were tested. Coal enrichment, aimed at adjusting its quality parameters to the requirements of various customers, is considered as a stage of mineral resources management. The adaptation of the quality of commercial coal products to the needs of specific customers consists in removing useless components from the excavated material. The processes of coal processing are carried out on various machines, the power of which reaches several dozen kilowatts. The energy of these machines, in addition to the useful power, is converted into heat, friction and noise. From the energy point of view, noise is not important, but it is very harmful to employees. The issue of noise pollution, although very dangerous to employees' health, is often underestimated. Due to the subjective perception of noise, it is not possible to determine the risk without proper research. The aim of this study was to determine where the noise standards are exceeded. The next step was to propose specific solutions to reduce the impacts of noise on health and work comfort.
\end{abstract}

Keywords: mechanical coal processing; noise; noise measurement; noise standards; noise prevention; noise protection

\section{Introduction}

Noise is a product of civilization that is often underestimated, but the negative effects of its impact have led to its recognition as a problem that needs to be formally faced. It usually refers to all unwanted, unpleasant, annoying or harmful mechanical vibrations of a medium, acting through the air on the hearing organ and other elements of human body. In order to protect against noise, the human body uses huge amounts of energy. It is possible to get used to noise, but this does not change the fact that it still has a destructive effect on the well-being and life functions of the human body. According to the World Health Organization, noise causes not only hearing damage and sleep disorders, but also cardiovascular diseases, including heart attacks and strokes. It is all the more dangerous because its effects rarely appear immediately-more often, they accumulate over time [1], although in extreme cases it can cause skin burns and immediate death [2]. In addition, high noise levels reduce people's ability to hear, communicate and warn each other, which increases the likelihood of errors at work and increases the risk of accidents. The need to raise the voice, forced by excessive noise, causes additional stress, which intensifies these adverse phenomena [3]. It is estimated that the social costs of noise amount to $0.4 \%$ of the European Union's GDP [4]. Therefore, it is reasonable to take action in order to identify workstations that are the sources of noise pollution. Then it is necessary to apply appropriate preventive measures for employees in workstations identified as dangerous. 
In this presented case, noise is created as a result of the unfavorable and unavoidable conversion of energy supplied for the coal processing into acoustic waves. From a physical point of view, it is the result of the overlapping of different sounds, which are mixed in a disorderly way. Sources of noise include the moving parts of machines and equipment, and processing, such as crushing or grinding. Noise in natural conditions is practically unavoidable. It accompanies us at home, at work, on a walk, and while using all of civilization's beneficial technology. The number of sources of noise is enormous, but industry is a special case due to noisy machines and equipment, as well as the means of transport.

This article presents the results of noise measurements at all workstations at the mechanical coal processing plant (ZMPW) in one of the mines of Jastrzębska Spółka Węglowa S.A. High-power processing machines generate considerable noise, which is not very important from the energy point of view, but significantly affects the safety and comfort of work. Hard coal mines are characterized by a large number of workstations that exceed noise standard limits. As a result, the hearing loss suffered by employees is irreversible, and largely limits their ability to work. Therefore, it can be concluded that noise is a very serious problem of modern mechanical coal processing [5]. According to the conducted tests, 42 workstations were identified in the analyzed mine that exceeded noise intensity standards. As many as 385 people at these workstations are exposed to excessive noise on a daily basis, 88 of whom are employees of the mechanical coal processing plant.

The harmful influence of noise on human health depends on many factors, such as the frequency of noise, noise intensity, exposure time, type of noise (intermittent, continuous, impulsive), individual susceptibility to noise, and the influence of other factors, e.g., ototoxic substances.

In order to assess the noise hazard, it has been assumed (in accordance with PN-EN ISO 9612:2009 standard) that the noise exposure level related to the $8 \mathrm{~h}$ daily working time $\left(L_{e x, 8 h}\right)$ should not exceed $85 \mathrm{~dB}\left(L_{d o p}\right)$, the maximum A-noise level $\left(L_{A \max }\right)$ should not exceed $115 \mathrm{~dB}$, and the $\mathrm{C}$-noise peak $\left(L_{\text {Cpeak }}\right)$ should not exceed $135 \mathrm{~dB}$ [6].

With the above values, it is easy to determine the level of occupational risk for employees resulting from exposure to audible noise by comparison with the limit values in force.

The studies in question comprehensively treat the entire technological sequence related to mechanical coal processing. The conducted tests take into account noise during work, breaks and in cabins or social rooms. In addition to assessing the nuisance and determining the risk of damage to health, a number of preventive measures are also proposed.

The problem of excessive noise is a well-known and widely discussed issue in the literature. However, in mining, this problem is often neglected, despite many new publications on the subject. The sources of noise in mining are the mining process and the working machines. There are papers on mining processes and the use of modern tools and computer techniques for designing cutting elements [7]. The problem of the energy consumption of the mining process is also discussed, depending on the types of applied tools and mining methods [8]. However, these studies did not discuss issues related to hazards such as pollination, sparking or noise. Modern quality engineering solutions are also introduced, for example for belt conveyors [9], whereby the authors propose a number of tools to improve the maintenance process by identifying the causes of long failures, shortening the downtime and applying preventive measures. In this paper, the economic effects of the applied solutions are indicated with the omission of health and safety at work.

In terms of research on the noise emitted by working machines, it is possible to find articles addressing this problem selectively. Engel et al. [10] have developed a theoretical model, and present results of simulation studies on the sound level for various devices, such as pumps, grinders, compressors or saws. Pleban, one of the publication's authors [10], continued his studies in this area and compared the simulation results with those for several dozen measurement points. Pleban carried out experimental studies for, among others, a combustion gas generator [11] and an industrial vacuum cleaner [12], determining noise in 
the three-dimensional space around. Pleban [13] conducted further studies also for open pit mining machines, analyzing the noise of crushers and vibrating conveyors in the open space of limestone mines. They carried out these studies for various measuring points in the vicinity of equipment, resulting in the sound intensity level depending on its frequency. Kosała and Stepień, on the other hand, carried out continuous and impulse noise tests in a quarry extracting anodesite [14]. In this article, the authors focused on the risks in individual worksites and in the surroundings of a mine, including working machines and the process of firing explosives. The measurements and simulations resulted in a three-axis map of noise pollution. It is also possible to find studies of noise generated by the machines used in a bauxite mine [15]. The authors noticed the problem of underestimating the noise hazard in India, and compared their results with standards enforced in their country. They found significant exceedances of the standards. In the analyzed case, the greatest noise was generated by hydraulic hammers, and much less was generated by breakers and bulldozers. Similarly, in the next article is presented the research results of noise generated by working machines in one of the Indian mines [16]. The authors not only showed that the noise generated by bulldozers and tippers exceeded the standards, but also drew attention to the source of this noise in the form of the individual components of these machines. Another study presents the working conditions of employees in the chrysotile mine in Kazakhstan [17]. Pointing out the very high risk caused by noise, the authors proposed preventive measures that were appropriate for this mine. A similar problem was addressed by Chebotarev and Courierov, using the results of noise and vibration studies for various workstations in Russian underground and open-pit mines [18]. The authors determined the number of employees suffering from noise and vibrations. In addition, they proposed the introduction of new solutions, such as cushioned seats for cabin acoustic insulation operators. The problem of excessive noise was also investigated in agriculture, among agricultural machinery workers in Thailand [19]. However, in Iran, the researchers analyzed the impact of noise on employees in the textile industry [20]. The problem of urban noise, known in urbanized areas, was also the subject of many studies. For example, international research was carried out in Oman, which drew attention to the main sources of noise in the form of vehicles, and the effects in the form of the irritation of cardiovascular problems [21]. There is also research on the effect of chronic noise exposure on hearing [22]. Another study offering a critical review of the literature on comfort-based hearing protection devices was made by Doutres et al. [23].

The literature analysis has shown that noise pollution studies are carried out very often, but selectively in different industries and at different workplaces. It should be noted that more and more attention is being paid to the safety and comfort of work in heavy industry. For example, the Mine Safety project focuses on identifying the current occupational health and safety (OSH) status of the extractive industries in five EU member states (Bulgaria, Czech Republic, Hungary, Poland, and Spain), with the assistance of the national and European associations and federations of the extractive sector [24].

The noise emitted during the mechanical processing of coal is influenced by many factors such as the type of machine, its technical condition, and the way that is fixed at the worksite. Due to the subjective perception of sounds, including noise, it is not possible to determine the harmfulness of a given worksite by means of appropriate tests. Studies carried out by other researchers, due to the specific nature of the processing machinery in question and the individual workstations, are not applicable. Moreover, it should be noted that in the European Union as well as in Poland, other regulations and requirements concerning permissible values describing noise are applied.

These are the first such research results in Poland, obtained for the mechanical processing of coal.

\section{Research Method}

The currently applied measurement method of values characterizing noise in the working environment is specified in the PN-EN ISO 9612:2009 standard [6]. For the mea- 
surement of noises emitted at workstations, sound exposure meters were used, including the integrating Class 1 sound level meter, called the SON-50, by Sonopan (Figure 1), measuring transient, fixed and impulse signals. The SON-50 is mainly used for measurements of values determining the employee's exposure to noise at the workstation, as well as environmental monitoring, and thanks to the possibility of attaching external octave or infrasound filters, it can be used for diagnostic tests of machines and equipment. It is a meter that enables the measurement of sound levels both at workstations and in the environment. It works in temperatures from $-10{ }^{\circ} \mathrm{C}$ to $+50{ }^{\circ} \mathrm{C}$ and up to $30 \%$ humidity, without measurement distortion results up to $150 \mathrm{~dB}$, with a resolution of $0.1 \mathrm{~dB}$ and a basic error not exceeding $\pm 0.7 \mathrm{~dB}$. Due to the resolution, the results are given to one decimal place.

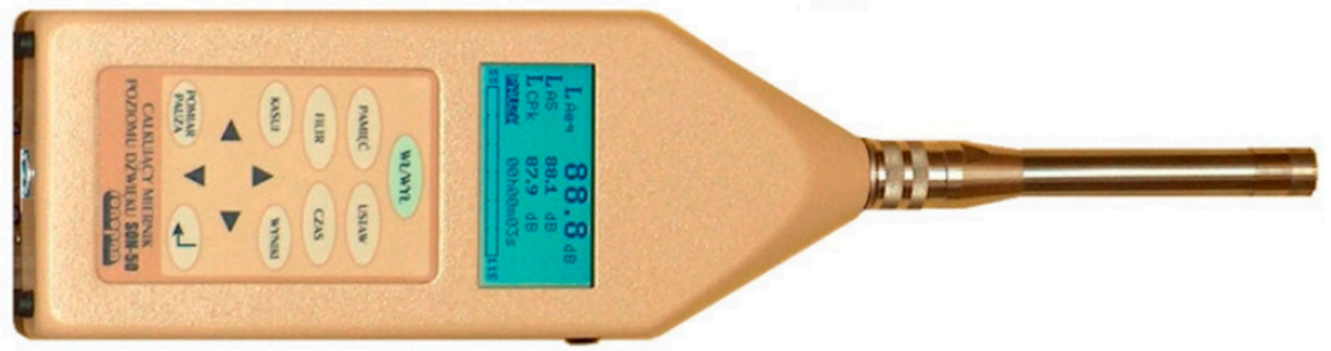

Figure 1. View of the Sonopan SON-50 device.

The meter has two independent measuring systems: an rms value to measure $L_{\text {Aeq }}$ $L_{A \max }$ and $L_{A \min }$, and a second one to measure the peak value $L_{C \text { peak }}$. This enables, for example, simultaneous measurements of the rms value via the A-characteristic and the peak value using the $\mathrm{C}$-characteristic. The device also measures the level of noise exposure related to the adjustable operating time (e.g. $L_{e x, 8 h}$ for $8 \mathrm{~h}$, etc.). One of its advantages is the simultaneous measurement of many important and complex parameters. The basis for the assessment of the noise level was the results of three measurements on each selected test station during the operation of a given machine or equipment.

One of the health risks that occur in mechanical coal processing plants is the noise emitted by machines and equipment involved in the technological systems of hard coal enrichment. The health risk of noise is identified in accordance with the existing and binding standards $[25,26]$, and refers to the maximum acceptable sound pressure levels (NDN) in the working environment, which are given in Refs. [27,28].

Due to the broadly understood interest of the company, the mine did not allow us to include photos of the mechanical coal processing plant in the paper.

For research purposes, six workstations were selected at three different units of the mechanical coal processing plant in one of JSW S.A.'s mines. These units are located on several levels, in three separate buildings (Table 1). The analyzed machines are typical machines for the mechanical processing of coal, commonly used in hard coal mines. During measurements, high-quality hard coking coal was processed. In order to differentiate the results, the study was carried out during work and breaks, and while staying in a cabin or social room. Measurements were conducted with the SON-50 device in accordance with the manufacturer's recommendations. The research was carried out in May 2020. Measurements were made on all three shifts from Monday to Friday during one week. The measured values correspond to those to which employees of particular workstations are exposed during their professional activities and during a break in their work. 
Table 1. Places and workstations for noise measurements.

\begin{tabular}{|c|c|c|}
\hline Mechanical Coal Processing Plant & Workstation & $\begin{array}{c}\text { Description of Work and Type of Activities Performed at the } \\
\text { Workstation }\end{array}$ \\
\hline \multirow{3}{*}{ Crushing Unit } & I & $\begin{array}{l}\text { Engineer of mechanical coal processing machines and } \\
\text { equipment-operation of skip haulage, level }+7.4 \mathrm{~m}\end{array}$ \\
\hline & II & $\begin{array}{l}\text { Engineer of mechanical coal processing machines and } \\
\text { equipment-operation of main screens, level }+15 \mathrm{~m}\end{array}$ \\
\hline & III & $\begin{array}{l}\text { Operation of tanks and loading and unloading equipment for coal } \\
\text { and stone-operation of equipment for raw coal tanks, level }+24 \mathrm{~m}\end{array}$ \\
\hline \multirow[b]{2}{*}{ Drilling Fluid Unit } & IV & Engineer of enrichment equipment-DISA separator operator \\
\hline & $\mathrm{V}$ & $\begin{array}{l}\text { Engineer of enrichment equipment-operation of heavy liquid } \\
\text { scrubber }\end{array}$ \\
\hline Flotation Unit & VI & $\begin{array}{c}\text { Engineer of water and sludge handling equipment, operation of SB } \\
6400 \text { centrifuges and ROOTSA blowers }\end{array}$ \\
\hline
\end{tabular}

\subsection{Calculation Methodology for Sound Pressure Levels}

According to the aforementioned standards, noise can be characterized by means of a number of values, for the calculation of which data from individual workstations are required. The basic measured value is the level of sound intensity and exposure time.

The noise level at the workstations was characterized by:

- $\quad$ exposure time to noise, min;

- A-weighted sound pressure level during the measurement $=L_{\text {Aeq }}$;

- A-sound maximum level $=L_{A \max }$;

- C-sound peak level $=L_{\text {Cpeak }}$;

- $\quad$ noise exposure level for $8 \mathrm{~h}$ working time $=L_{e x, 8 h}$.

The indicator for noise assessment in the working environment is A-weighted sound pressure level $-L_{A e q}$, which is a measure of the value of acoustic energy averaged over time.

If the time interval of the $T_{O}$ measurement is divided into smaller time intervals $T_{e}$, the A-weighted sound pressure level, in $\mathrm{dB}$, is calculated according to the equation:

$$
L_{\text {Aeq }}=10 \lg \left[\frac{1}{n} \sum 10^{L_{\text {Aeq, Te } / 10}}\right][d B]
$$

where:

$L_{A e q, T e}-\mathrm{A}$-weighted equivalent sound pressure level adjusted by frequency characteristics, in the time interval $T_{e}$;

$n$-number of elementary measurements in a series.

The noise exposure level in relation to an $8 \mathrm{~h}$ working day $L_{e x, 8 h}$ can be calculated according to the equation [27]:

$$
L_{e x, 8 h}=L_{A e q}+10 \log \frac{T_{E}}{T_{O}}[d B]
$$

where:

$L_{\text {Aeq }}-\mathrm{A}$-weighted sound pressure level;

$T_{E}$ - exposure time, in min, during the working day;

$T_{O}$-reference time equal to $8 \mathrm{~h}$ (480 $\mathrm{min}$ ), or using the daily noise exposure calculator in the special spreadsheet. 


\subsection{Calculation Methodology for Hearing Loss Risk}

For proper risk assessment, the principle described in PN-N-180002-Health and Safety Management Systems should be adopted. These are the general guidelines for occupational risk assessment (criterion of harmfulness to the hearing organ), taking into account the multiplication factor $\left(K_{e x, 8 h}\right)$ and the maximum intensity limit [27].

The value of $L_{e x, 8 h}$ with respect to $L_{d o p}$ is calculated according to the equation:

$$
K_{e x, 8 h}=10^{0.1\left(L_{e x, 8 z}-L_{d o p}\right)}
$$

where:

$L_{e x, 8 h z}$-measured $L_{e x, 8 h} ;$

$L_{d o p}$-acceptable level, $85 \mathrm{~dB}$.

Therefore, the following obtains:

$K<0.5$ - small risk;

$0.5 \leq K \leq 1.0$-medium risk;

$K>1.0$ - high risk.

Small and medium risks are considered acceptable, while high risk is unacceptable in the working environment [27].

The following equation was used to determine the exceeding limit value $\left(P_{d o p}\right)$ for $L_{e x, 8 h}$ :

$$
P_{d o p}=L_{e x, 8 h z}-L_{d o p}[d B]
$$

In order to calculate the working time limit at the workstations, the following equation must be used:

$$
T_{\text {dop }}=\frac{T_{O}}{10^{0.1\left(L_{\text {Aex }}-L_{\text {Adop }}\right)}}[\mathrm{min}]
$$

where:

$T_{d o p}$-exposure limit time in min;

$L_{A e x}-\mathrm{A}$-weighted sound pressure level in $\mathrm{dB}$;

$L_{\text {Adop }}-\mathrm{A}$-weighted sound pressure level in relation to $8 \mathrm{~h}$ exposure in $\mathrm{dB}$.

\section{Elaboration and Analysis of Research Results}

The research results for individual workstations were collected in the form of a table. Subsequently, for the obtained results and according to the methodology, the required calculations were conducted. As a result, the noise values were obtained and the risk of hearing damage at individual workstations was determined [29].

\subsection{Research Results}

The measurement results presented in Table 2 were used to compare working conditions with the acceptable standards, and to determine the risk of hearing damage at the workstation by analyzing the exceeded limit values and the multiple of the noise limit values for 8 working hours. Each of the listed workstations was evaluated on the basis of the technical and organizational protection measures applied. The measurements and their analysis were necessary to consider the choice of additional measures aimed at reducing exposure to noise. 
Table 2. Results of noise measurements at six workstations in the mechanical coal processing plant.

\begin{tabular}{|c|c|c|c|c|c|c|c|}
\hline Workstation & No. & Measurement Sites & $\begin{array}{l}\text { Exposure } \\
\text { Time (min) }\end{array}$ & $L_{A e q}(\mathrm{~dB})$ & $L_{\text {Amax }}(\mathrm{dB})$ & $L_{\text {Cpeak }}(\mathrm{dB})$ & $L_{e x, 8 h}(\mathrm{~dB})$ \\
\hline \multirow{3}{*}{ Workstation I } & 1. & $\begin{array}{l}\text { Operation of skip haulage } \\
\text { equipment_area of } \\
\text { picking belts }\end{array}$ & 120 & 94.0 & 102.6 & 120.3 & \multirow{3}{*}{88.0} \\
\hline & 2. & Measurement in the social room & 240 & 58.4 & 73.4 & 90.4 & \\
\hline & 3. & $\begin{array}{l}\text { Maintenance and cleaning } \\
\text { work-machine downtime }\end{array}$ & 120 & 70.0 & 78.2 & 98.2 & \\
\hline \multirow{3}{*}{$\begin{array}{l}\text { Workstation } \\
\text { II }\end{array}$} & 1. & $\begin{array}{c}\text { Feeder operation control } \\
\text { Operation control of screens }\end{array}$ & 180 & 91.4 & 96.2 & 116.7 & \multirow{3}{*}{87.2} \\
\hline & 2. & Measurement in the cabin & 180 & 71.2 & 79.2 & 99.1 & \\
\hline & 3. & $\begin{array}{l}\text { Maintenance and cleaning } \\
\text { works-plant downtime }\end{array}$ & 120 & 70.2 & 79.9 & 99.8 & \\
\hline \multirow{5}{*}{$\begin{array}{l}\text { Workstation } \\
\text { III }\end{array}$} & 1. & $\begin{array}{c}\text { Cleaning and maintenance } \\
\text { works-belt drive area } \\
2.101 / 1.2 \text { level }+24 \mathrm{~m}\end{array}$ & 60 & 91.7 & 94.4 & 113.0 & \multirow{5}{*}{85.0} \\
\hline & 2. & $\begin{array}{c}\text { Cleaning and maintenance } \\
\text { work in the drive area } 2.115\end{array}$ & 30 & 91.6 & 94.0 & 113.0 & \\
\hline & 3. & $\begin{array}{l}\text { Control of filling level of raw } \\
\text { coal tanks level }+19 \mathrm{~m}\end{array}$ & 120 & 83.9 & 88.3 & 109.6 & \\
\hline & 4. & Measurement in the cabin & 180 & 67.6 & 74.8 & 94.8 & \\
\hline & 5. & $\begin{array}{l}\text { Maintenance and cleaning } \\
\text { work-machine downtime }\end{array}$ & 90 & 70.0 & 77.8 & 97.3 & \\
\hline \multirow{5}{*}{$\begin{array}{l}\text { Workstation } \\
\text { IV }\end{array}$} & 1. & Control of DISA separator & 120 & 91.1 & 94.1 & 112.7 & \multirow{5}{*}{85.7} \\
\hline & 2. & $\begin{array}{l}\text { Measurement in the } \\
\text { control cabin }\end{array}$ & 190 & 70.7 & 75.3 & 85.2 & \\
\hline & 3. & $\begin{array}{l}\text { Maintenance and cleaning } \\
\text { work-machine downtime }\end{array}$ & 125 & 74.7 & 86.1 & 98.2 & \\
\hline & 4. & $\begin{array}{l}\text { Recuperator support } \\
\text { level }+25 \mathrm{~m}\end{array}$ & 30 & 87.8 & 94.2 & 115.1 & \\
\hline & 5. & Social break & 15 & 58.7 & 65.2 & 98.2 & \\
\hline \multirow{4}{*}{$\begin{array}{l}\text { Workstation } \\
\qquad \mathrm{V}\end{array}$} & 1. & $\begin{array}{l}\text { Operation control of equipment } \\
\text { in the facility no. } 3 \text { level 9-29 m }\end{array}$ & 240 & 89.5 & 97.1 & 116.2 & \multirow{4}{*}{86.6} \\
\hline & 2. & $\begin{array}{l}\text { Measurement in the } \\
\text { control cabin }\end{array}$ & 125 & 68.1 & 73.4 & 94.1 & \\
\hline & 3. & $\begin{array}{l}\text { Maintenance and cleaning } \\
\text { work-machine downtime }\end{array}$ & 100 & 73.4 & 86.4 & 104.8 & \\
\hline & 4. & Social break & 15 & 58.7 & 65.2 & 98.2 & \\
\hline \multirow{4}{*}{$\begin{array}{l}\text { Workstation } \\
\text { VI }\end{array}$} & 1. & $\begin{array}{l}\text { Operation of centrifuges } \\
\text { SB-6400, blowers level }+27\end{array}$ & 90 & 94.0 & 97.3 & 118.2 & \multirow{4}{*}{87.1} \\
\hline & 2. & $\begin{array}{l}\text { Control and operation of } \\
\text { centrifuges } \\
\text { SB-6400-measurement in } \\
\text { the cabin }\end{array}$ & 240 & 63.1 & 66.7 & 90.7 & \\
\hline & 3. & $\begin{array}{l}\text { Maintenance and cleaning } \\
\text { work-machine downtime }\end{array}$ & 120 & 72.6 & 79.9 & 96.6 & \\
\hline & 4. & $\begin{array}{c}\text { Operation control of conveyors } \\
5.34,5.35, \text { level }+24\end{array}$ & 30 & 87.1 & 92.4 & 113.7 & \\
\hline
\end{tabular}


When assessing the compliance of working conditions with the requirements at selected workstations, it can be concluded that the maximum A-noise level $\left(L_{A \max }\right)$ and $C$-noise peak $\left(L_{\text {Cpeak }}\right)$ do not exceed the value limit, while the level of noise exposure for $8 \mathrm{~h}$ work $\left(L_{e x, 8 h}\right)$ exceeds the value limit at each of the six analyzed workstations at the mechanical coal processing plant (Figure 2).

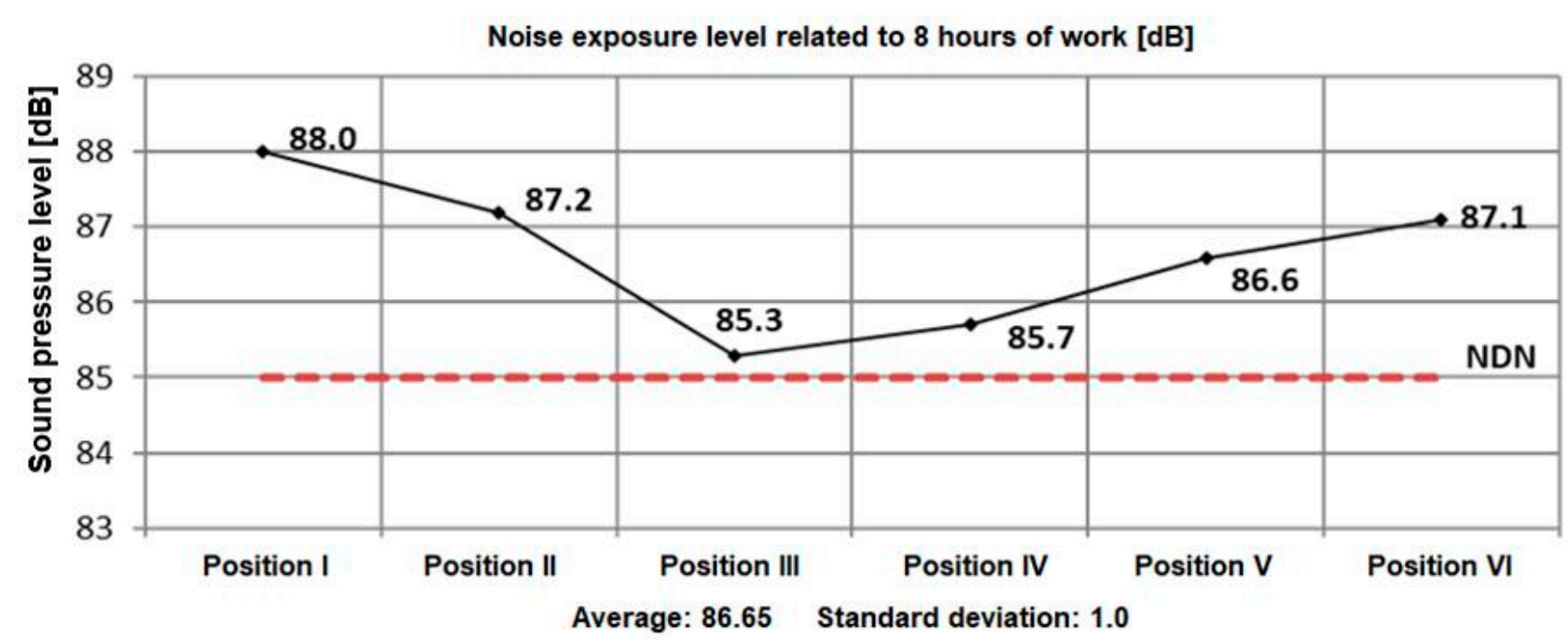

Figure 2. Analysis of the noise level $8 \mathrm{~h}$ daily working time $\left(L_{e x, 8 h}\right)$ in comparison with the acceptable standard (NDN) at the workstation of the mechanical coal processing plant.

\subsection{Elaboration of Research Results}

At each of the analyzed workstations, the level of $L_{e x, 8 h}$ varies between 85.3 and $88 \mathrm{~dB}$. This results from the details of the work, and the operation of devices emitting noise above the maximum intensity limit (NDN) (i.e., pumps, separators, fans, etc.). All these machines emit noise above $85 \mathrm{~dB}$, with some even exceeding $94 \mathrm{~dB}$ (Table 3).

Table 3. List of devices in the mechanical coal processing plant emitting noise above NDN.

\begin{tabular}{ccccc}
\hline No. & $\begin{array}{c}\text { Mechanical Coal Processing Plant } \\
\text { Machines and Equipment }\end{array}$ & $\begin{array}{c}\text { Noise Emitted by the } \\
\text { Machine (dB) }\end{array}$ & $\begin{array}{c}\text { Working Time } \\
\text { (min/Shift) }\end{array}$ & Working Time (h/Day) \\
\hline 1. & Jigging machines & 90.4 & 240 & 12 \\
2. & Heavy liquid circulation equipment & 89.4 & 240 & 12 \\
3. & DISA separators & 93.1 & 240 & 12 \\
4. & WOW dehydrators & 89.4 & 240 & 12 \\
5. & Fans & 94 & 30 & 1.5 \\
6. & Disc filters & 94 & 300 & 4.5 \\
7. & Picking belts & 95.4 & $90-240$ & $4-12$ \\
8. & Belt and scraper conveyors & $86-92.7$ & 120 & 6 \\
9. & Pumps PH-150 & 91.7 & 120 & 6 \\
10. & Water and sludge pumps & $87.8-94.1$ & & \\
\hline
\end{tabular}

On the basis of the conducted calculations, it was found that at each of the mechanical coal processing plant's workstations, the multiple of the limit value for the $8 \mathrm{~h} K_{e x, 8 \mathrm{~h}}$ working time exceeds one. The risk of occupational hearing damage is thus high, reaching unacceptable levels, so it is very important to use earmuffs or earplugs when performing all activities at these workstations. If earplugs are used properly, the risk of occupational injury is reduced to small. For all six workstations, the calculations of exceeded limits of $L_{e x, 8 h}$, the multiple of the limit value for $L_{e x, 8 h}$, and the limit of exposure time to noise 
were carried out in an identical way, based on equations $P_{d o p}, K_{e x, 8 h}$ and $T_{d o p}$. The obtained results are presented in Table 4 and Figure 3.

Table 4. Noise analysis at individual workstations of the mechanical coal processing plant.

\begin{tabular}{|c|c|c|c|c|c|c|}
\hline \multicolumn{2}{|c|}{$\begin{array}{l}\text { Mechanical Coal Processing } \\
\text { Plant/Workstation }\end{array}$} & $\begin{array}{c}\text { Noise } \\
\text { Exposure Level } \\
\text { for } 8 \mathrm{~h} L_{e x, 8 h} \\
\text { (dB) }\end{array}$ & $\begin{array}{l}\text { Exceeded } \\
\text { Limit } L_{e x, 8 h} \\
\text { (dB) }\end{array}$ & $\begin{array}{c}\text { Multiple of } \\
L_{e x, 8 h}(\mathrm{~dB}) \\
\text { Noise Limit } \\
\text { Value }\end{array}$ & $\begin{array}{l}\text { Working Time } \\
\text { Limit at the } \\
\text { Workstation } \\
\text { (min) }\end{array}$ & $\begin{array}{c}\text { Risk of } \\
\text { Hearing } \\
\text { Damage }\end{array}$ \\
\hline \multirow{3}{*}{ Crushing } & I & 88.0 & 3.0 & 2.00 & 240 & high \\
\hline & II & 87.2 & 2.2 & 1.66 & 289 & high \\
\hline & III & 85.3 & 0.3 & 1.07 & 447 & high \\
\hline \multirow{2}{*}{ Drilling Fluid } & IV & 85.7 & 0.7 & 1.17 & 408 & high \\
\hline & $\mathrm{V}$ & 86.6 & 1.6 & 1.45 & 332 & high \\
\hline Flotation & VI & 87.1 & 2.1 & 1.62 & 295 & high \\
\hline
\end{tabular}

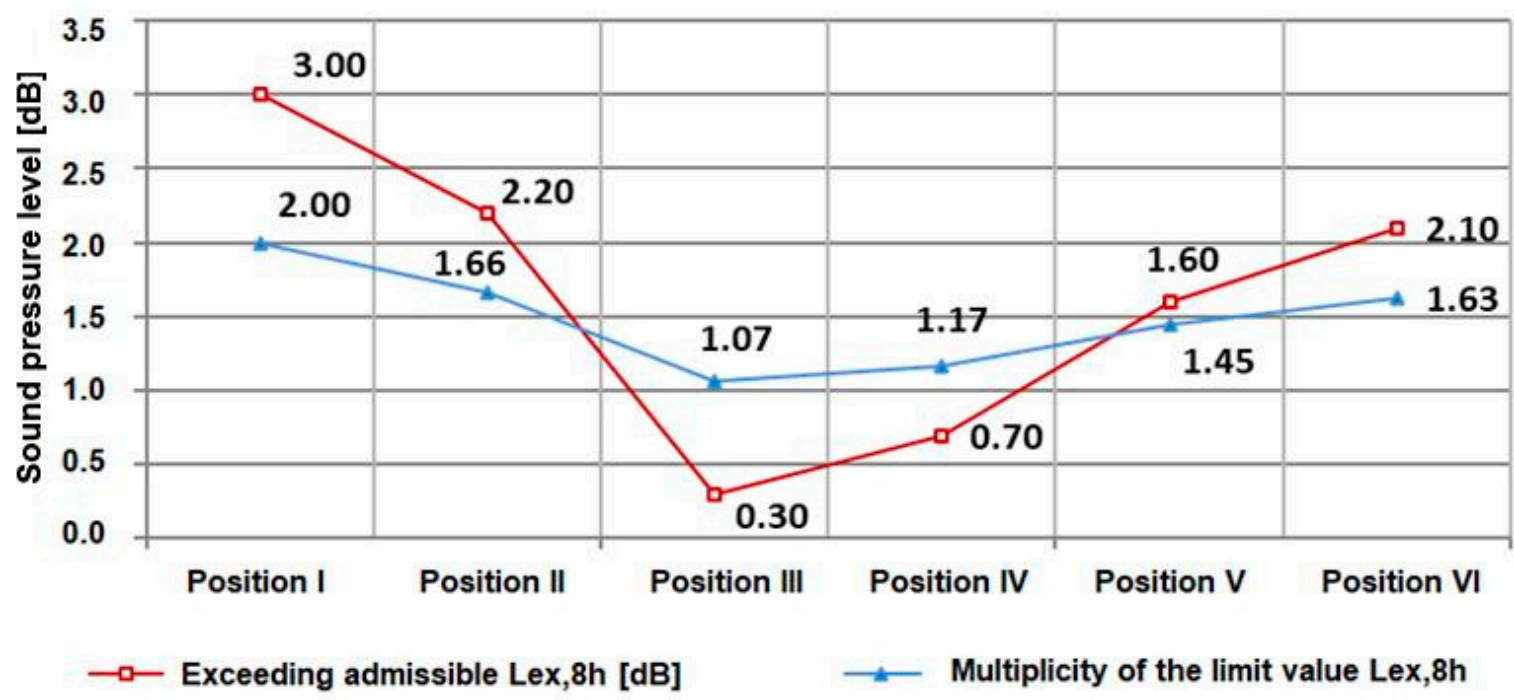

Figure 3. Exceeded limit value and multiple of the noise limit value for 8 working hours for selected workstations of the mechanical coal processing plant.

\subsection{Analysis of Research Results}

On the basis of a detailed analysis of noise measurements carried out at the mechanical coal processing plant, it can be concluded that at each of the analyzed workstations, noise standard limits are exceeded. The highest exposure of an employee to excessive noise occurs at three workstations: workstations I and II and workstation VI. During a working day of several hours, employees are exposed to discomfort caused by long-term exposure to noise. A working environment with a high level of noise affects rapid fatigue and problems with concentration, lowering the psychomotor efficiency of an employee. The effects of noise on the human body are rarely revealed immediately. After a few, or sometimes even more than a dozen or so, years, they may be the cause of many negative changes, not only in the hearing organ but also in other parts of the human body.

At each of the six analyzed workstations of the mechanical coal processing plant, different types of measures were applied to protect the employees from noise. Some of the social rooms and installed sound-absorbing cabins need to be replaced with new ones. However, this protection is not sufficient, as the employee is forced to leave the cabin in order to inspect the work of machines and equipment. In this case, the proper use of personal hearing protectors (earmuffs and earplugs) is necessary. 


\section{Proposed Preventive Measures}

It is technically impossible to completely eliminate the sources of excessive noise from the premises of the mechanical coal processing plant. In order to change this state of affairs, a number of technical and organizational measures are applied, aimed at reducing noise levels, limiting the number of employees exposed to this factor, as well as reducing the risk of occupational diseases. An example would be the modernization of dispatching systems (related to the operation of processing plant), consisting of the elimination of staff from workstations exposed to particular health risks, or the reconstruction of the raw coal preparation station. Reconstruction consists of replacing crushers. In the place of louder Brieden jaw crushers, Bradfordt drum crushers were used.

The mine is undertaking organizational and technical activities aimed at improving work safety. A special program for the comprehensive prevention of occupational hearing damage has been implemented.

This program is particularly focused on:

- lists of sources of noise in the work environment;

- identifying workstations exposed to excessive noise;

- constant monitoring of the workstations with excessive noise standards;

- identifying groups of diverse risks;

- $\quad$ raising employees' health awareness;

- increasing the competence level of preventive services;

- periodic evaluation of the effectiveness of the implemented program.

An appropriate solution in this situation would be a comprehensive replacement of the machine park with a new one, with limited noise emission. However, such a solution involves large financial costs, and can only be implemented gradually. The replacement of machinery and equipment is planned for over the next few years. Therefore, it is necessary to introduce all measures that could improve comfort at workstations.

The latest methods and preventive measures were analyzed, as well as system solutions and personal protective equipment. Consultations were held with mine employees and manufacturers of suitable protective equipment. As a result, the possible and most promising measures for reducing the adverse effects of noise on employees were selected.

In practice, apart from the systematic introduction of mining machinery and equipment with lower noise emission, a number of complex solutions should be applied to reduce the employee's exposure to noise, such as the selection of appropriate protective measures:

- the installation of new, properly designed sound-absorbing cabins in place of old cabins and social rooms;

- the replacement of previously used disposable earplugs with more comfortable active reusable earplugs.

Soundproof cabins for operators are used on the premises of the mechanical coal processing plant in halls where it is possible for an employee to stay temporarily in the cabin. These are social and recreation rooms, located in different places on the premises of the processing plant, intended for employees operating machines and equipment. Apart from technical requirements that protect against noise, sound-insulating cabins must also meet a number of hygienic, sanitary and operational requirements.

Soundproof cabins intended for use in mechanical coal processing plants should be characterized by the following features:

- proper protection against noise-about $80 \%$ of the surface, that is, floor, ceiling, walls and windows, covered with sound-absorbing materials;

- appropriate dimensions (door height: $2.35 \mathrm{~m}$; cabin height, internal: $2.40 \mathrm{~m}$; exterior: $2.75 \mathrm{~m}$; volume inside the cabin: $15 \mathrm{~m}^{3}$; wall thickness: $85 \mathrm{~mm}$ );

- location on the elevation (approx. $50 \mathrm{~cm}$ from the hall floor on a wooden platform lined with rubber covers on both sides); 
- equipped with electricity, interior lighting, and a telephone enabling constant communication with the mine's supervisors;

- appropriate heating and air conditioning as well as ventilation;

- proper visibility of machines and equipment;

- appropriate distance from the nearest sound source (machines and equipment).

Therefore, the proposal to install cabins with so-called "telescopic" construction is the right solution for the improvement of work comfort on the premises of the mechanical coal processing plant (Figure 4). A modern cabin should be built of materials with the highest possible sound absorption (insulation and construction of the cabin selected according to the type of noise); it should have an elevated floor with the appropriate number of windows. The cabin is at least $10 \mathrm{~m}$ away from machines and should have an installed sliding door with a vestibule.

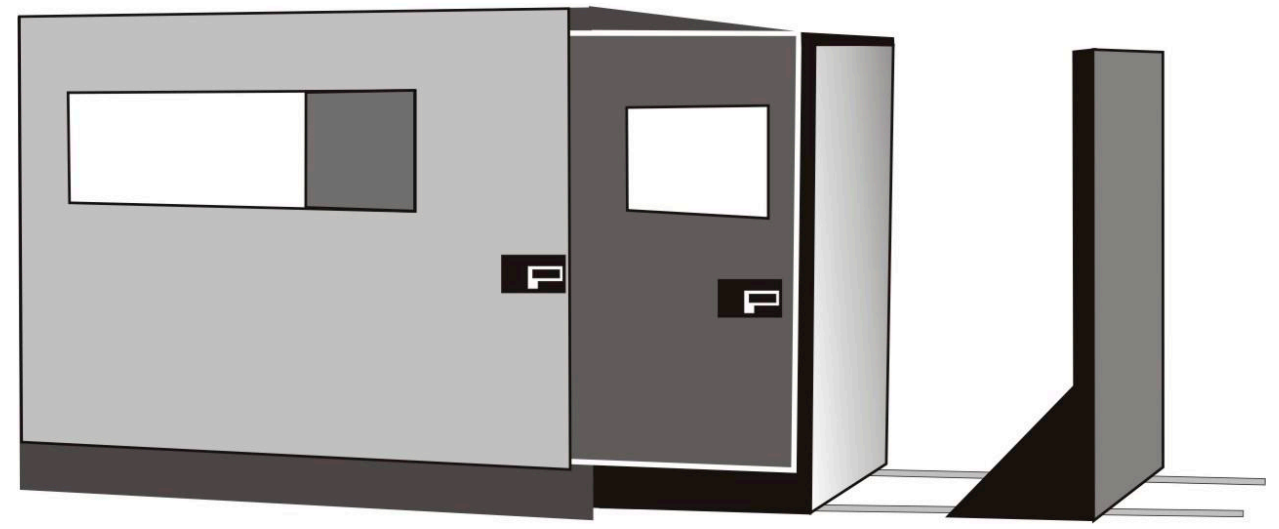

Figure 4. Soundproof cabin with telescopic design.

The cabin's doors and windows are an element that affects the acoustic efficiency. The sliding element with a double door reduces the noise getting inside the cabin. The applied solution allows for greater noise protection inside the cabin. The door moves on rails while extending. The cabin has a window with double-glazed soundproofing of different thicknesses, with the use of attenuation in the spaces between the windows (windows connected by several layers of soundproof foil). In order to improve the acoustic efficiency, sound insulation in the cabin interior was used.

Another solution for individual employee protection is active earplugs, e.g., Surefire EarPro EP7 Ultra Sonic Defenders earplugs (Figure 5), with a double level of protection (they have additional mini-plugs inside if the basic protection is insufficient).

These earplugs are produced in three sizes (small, medium, large), although the vast majority of people use a medium size. The earplugs fit anatomically into the ear (matching the size of auricle) and stick very firmly, without disturbing. The method of putting on the earplugs is presented in Figure 5.

The earplugs protect hearing while allowing communication between employees and over the phone. They are made of a soft polymer, and are durable and hypoallergenic. They provide comfort and safety throughout the day, can be used from 3 to 6 months, depending on the nature of use. The earplugs are designed in such a way that they can be worn with a helmet or mask, or with a headset. They respond to noise levels above $85 \mathrm{~dB}$, reducing it to $24 \mathrm{~dB}$. 
The sizes-small, medium, and large-refer only to the outer earpieces that fit in the ear's concha bowl and help hold the EP3 in place. Proper EP3 size is based on the dimensions of your ear's concha bowl. Medium fits most people.

For those with larger ear canals, the EP4's three-flange stem may provide a better fit than the EP3's two-flange stem.
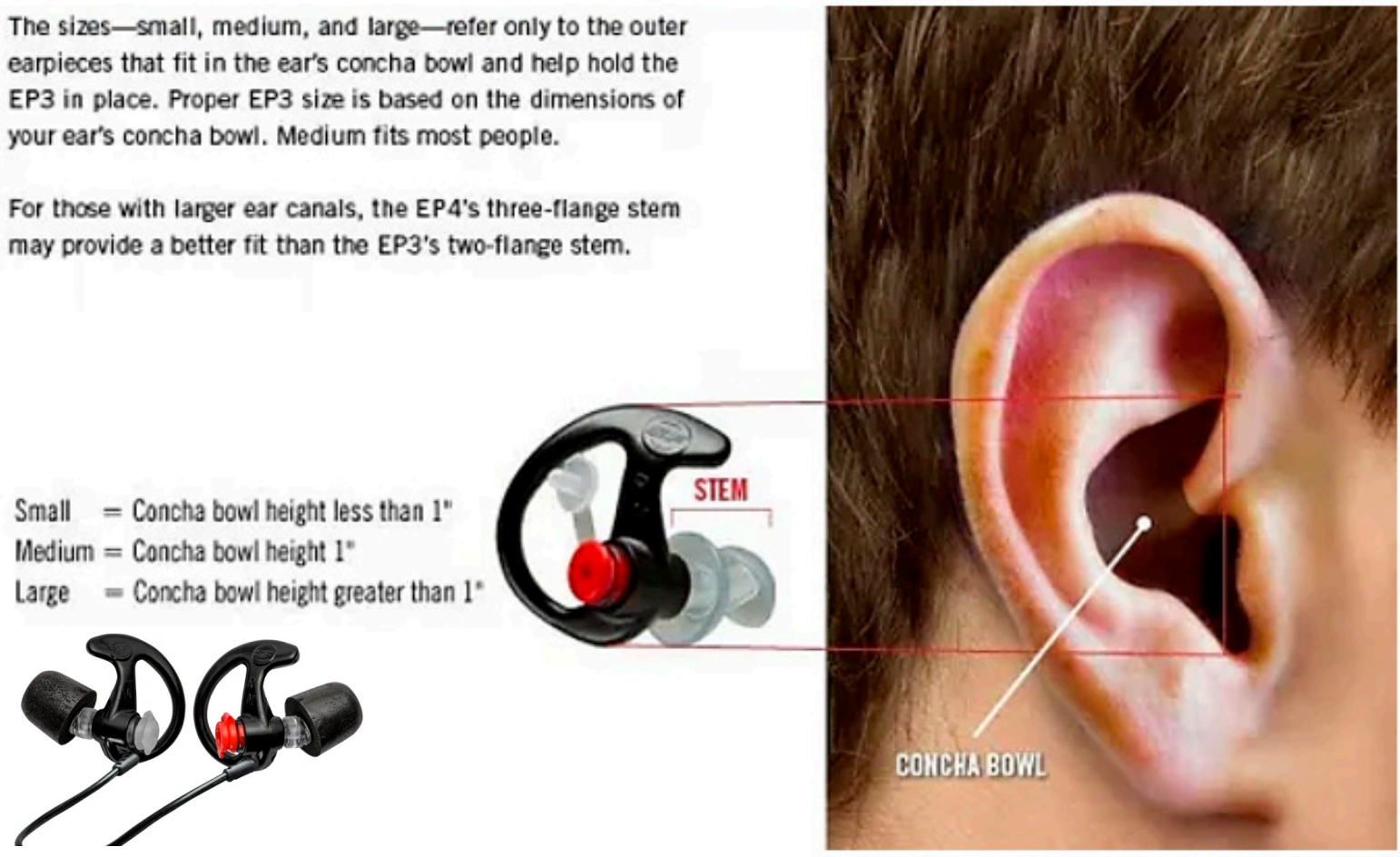

Figure 5. Surefire EarPro EP7 Ultra Sonic Defenders earplugs.

\section{Conclusions}

The results of noise tests carried out in real conditions at the mechanical coal processing plant, in one of the Jastrzębska Spółka Weglowa (JSW S.A.) mines, showed that noise standards were exceeded at three workstations. This applies to the workstations designated as I, II and VI. The work at each of these stations is associated with a high risk of hearing damage. This is mainly due to the specificity of workplaces, i.e., the operation of machines emitting noise above the maximum admissible concentration (NDN). All of these machines emit noise above $85 \mathrm{~dB}$, with some even exceeding $94 \mathrm{~dB}$ (see Table 3).

The tests were carried out during work, during breaks, and while staying in a cabin or social room. At each of the six analyzed workstations, measures were taken to protect the employees from noise, which proved to be insufficient. A number of necessary preventive measures were proposed to improve occupational safety with regard to noise risks.

Properly designed, comfortable hearing protectors will help employees not only protect their hearing, but also communicate with each other. It is expected that individual protectors or active earplugs will be willingly worn before entry into a noisy section of the mechanical coal processing plant, and upon leaving the telescopic noise cabins.

As a result of the conducted noise measurements, places within ZMPW's production process were indicated that should be given special attention. For the assessment of noise pollution, it has been assumed (in accordance with PN-EN ISO 9612:2009) that the level of noise exposure associated with the 8 daily working hours $\left(L_{e x, 8 h}\right)$ should not exceed $85 \mathrm{~dB}$, the A-sound level $\left(L_{\text {Amax }}\right)$ should not exceed $115 \mathrm{~dB}$, and the C-sound peak level $\left(L_{\text {Cpeak }}\right)$ should not exceed $135 \mathrm{~dB}$. Knowledge of these values allowed us to determine the level of occupational risk for the employees resulting from exposure to audible noise by comparison with the applicable limit values. In each of the six analyzed workstations, the risk of hearing damage is high.

The analysis allows us to specify individual ZMPW processes in terms of the noise level generated. On this basis, it is possible to make decisions related to the modernization of individual technological processes. Replacing an efficient machine park because of the level of generated noise alone is not economically justified. Therefore, recommendations 
have been developed in the form of possible countermeasures. The most promising solutions were selected. The proposed cabins and personal protective equipment were selected after taking into account the employees' comments and preferences. Additionally, in order to ensure the best possible selection of these measures given the specific details of the ZMPW, consultations were held with their manufacturers.

However, the modernization and replacement of machinery and equipment, the location of modern sound-absorbing cabins, and the use of active earplugs are not sufficient to effectively and successfully combat noise. Both detailed research on risk analysis, and the use of modern, active methods of noise reduction or actions involving, among other things, removing an employee from places with high noise levels, are needed. Robotization and automation in mining starts with the most dangerous workstations. Due to the very difficult working conditions, automated longwall complexes or remotely controlled roadheaders are used [30]. Mechanical processing, which takes place on the surface, generates a hazard for employees in the form of dust and noise. Personal protective equipment effectively eliminates the risk of dust. In the case of noise, the problem is still unresolved.

If the safe noise level has been exceeded at the workplace, employees have a shorter working time. However, any exposure to noise, even at a permissible level, causes permanent damage to health over many years of work. It is, therefore, also in the interest of employees to apply appropriate preventive measures.

The research in question, conclusions developed and preventive measures proposed allow for a broader view of the problem concerning noise, to which the employees of mechanical coal processing plants are exposed. This issue was previously underestimated, due to the lack of appropriate evidence in the form of comprehensive research. It is to be expected that in the future, following the example of already known solutions, remote control, diagnostics and supervision systems of processing machines will be used. This will limit the operation of processing machines to the inspections and repairs that take place when they are shut down.

Author Contributions: Ł.B. analysis of literature and state of knowledge; J.S. plan and methodology of research; W.B., Ł.B., J.S. implementation of research; W.B. elaboration of research results; W.B. analysis of research results; J.S. assessment of hearing impairment risk; Ł.B. proposal of countermeasures; W.B. analysis and interpretation of results; Ł.B. elaboration of paper. All authors have read and agreed to the published version of the manuscript.

Funding: The research was conducted with the support of the statutory work project number 13/030/BK-21/0065.

Data Availability Statement: Data is contained within the article.

Acknowledgments: Acknowledgements to Jastrzębski Spółka Węglowa S.A. for enabling the research and logistic support.

Conflicts of Interest: The authors declare no conflict of interest.

\section{References}

1. Marek, K. Choroby Zawodowe; Wydawnictwo Lekarskie PZWL: Warszawa, Poland, 2003.

2. Czeskin, M.S. Człowiek i Hałas; Państwowe Wydawnictwa Naukowe: Kraków, Poland, 1972.

3. Puzyna, C. Ochrona Środowiska Pracy Przed Hałasem; Wydawnictwa Naukowo-Techniczne: Warszawa, Poland, 1982.

4. Delft, E.C. Health Effects, Social Costs and Technical and Policy Options to Reduce Road and Rail Traffic Noise. Available online: http:/ / www.transportenvironment.org/docs/Publications/2008/2008-02_traffic_noise_ce_delft_report.pdf (accessed on 14 February 2021).

5. Biały, W.; Żukowska, T. Przekroczenia hałasu na terenie zakładu przeróbki mechanicznej węla. In Rola Informatyki w Naukach Ekonomicznych i Społecznych; Tom 1; Wydawnictwo Wyższej Szkoły Handlowej: Kielce, Poland, 2011.

6. $\quad$ PN-EN ISO 9612:2009 Hałas. Dopuszczalne wartości hałasu w środowisku pracy. In Wymagania Dotyczace Wykonywania Pomiarów.

7. Bołoz, Ł.; Castañeda, L.F. Computer-Aided Support for the Rapid Creation of Parametric Models of Milling Units for Longwall Shearers. Manag. Syst. Prod. Eng. 2018, 26, 193-199. [CrossRef]

8. Kotwica, K.; Małkowski, P.; Krzysztof, K.; Piotr, M. Methods of Mechanical Mining of Compact-Rock-A Comparison of Efficiency and Energy Consumption. Energies 2019, 12, 3562. [CrossRef] 
9. Zasadzień, M.; Midor, K. Statistical Process Control as a Failure Removal Improvement Tool. Acta Technol. Agric. 2018, 21, 124-129. [CrossRef]

10. Engel, Z.; Pleban, D.; Stryczniewicz, L. Investigation of emission sound pressure using inversive method. Arch. Acoust. 2002, 27, 277-290.

11. Pleban, D. Experimental modelling and research on vibroacoustic phenomena in machines. Arch. Acoust. 2004, $29,219-233$.

12. Pleban, D. Acoustic modelling of machines using the inversion method for the purposes of the acoustic assessment of machines. Arch. Acoust. 2007, 32, 321-327.

13. Pleban, D.; Piechowicz, J.; Kosała, K. The Inversion Method in Measuring Noise Emitted by Machines in Opencast Mines of Rock Material. Int. J. Occup. Saf. Ergon. 2013, 19, 321-331. [CrossRef] [PubMed]

14. Kosała, K.; Stępien, B. Analysis of noise pollution in an andesite quarry with the use of simulation studies and evaluation indices. Int. J. Occup. Saf. Ergon. 2016, 22, 92-101. [CrossRef] [PubMed]

15. Kisku, G.C.; Barman, S.C.; Kidwai, M.M.; Bhargava, S.K. Environmental impact of noise levels in and around opencast bauxite mine. J. Environ. Biol. 2002, 23, 51-56. [PubMed]

16. Vardhan, H.; Karmakar, N.; Rao, Y. Assessment of heavy earth-moving machinery noise vis-a-vis routine maintenance. Noise Control. Eng. J. 2006, 54, 64. [CrossRef]

17. Ibraev, S.A.; Zharylkassyn, Z.H.; Izdenov, A.K.; Alekseev, A.V.; Tilemissov, M.K. Hygienic Assessment of Noise of Mobile Machinery of Transportation Company in Mining Industry. Res. J. Pharm. Biol. Chem. Sci. 2016, 7, $2236-2238$.

18. Chebotarev, A.; Courierov, N. Hygienic Assessment of Noise and Vibration Affecting Workers at Mining Operations. Min. Ind. J. (Gorn. Promishlennost) 2020, 1, 148-153. [CrossRef]

19. Choochouy, N.; Kongtip, P.; Chantanakul, S.; Nankongnab, N.; Sujirarat, D.; Woskie, S.R. Hearing Loss in Agricultural Workers Exposed to Pesticides and Noise. Ann. Work. Expo. Heal. 2019, 63, 707-718. [CrossRef] [PubMed]

20. Shabani, F.; Alimohammadi, I.; Abolghasemi, J.; Dehdari, T.; Ghasemi, R. The study of effect of educational intervention on noise annoyance among workers in a textile industry. Appl. Acoust. 2020, 170, 107515. [CrossRef]

21. Amoatey, P.; Omidvarbona, H.; Baawain, M.S.; Al-Mayahi, A.; Al-Mamun, A.; Al-Harthy, I. Exposure assessment to road traffic noise levels and health effects in an arid urban area. Environ. Sci. Pollut. Res. 2020, 27, 35051-35064. [CrossRef] [PubMed]

22. Mohammadi, I.A.; Kanrash, F.A.; Abolghasemi, J.; Rahmani, K. The Effects of Chronical Noise-Exposure on Hearing Ability, Psychological, and Mental Attitude of Workers in Automotive Industry. J. Tolooebehdasht 2019, 18, 17-31. [CrossRef]

23. Doutres, O.; Sgard, F.; Terroir, J.; Perrin, N.; Jolly, C.; Gauvin, C.; Negrini, A. A critical review of the literature on comfort of hearing protection devices: Analysis of the comfort measurement variability. Int. J. Occup. Saf. Ergon. 2020, 14, 1-12. [CrossRef] [PubMed]

24. Mine Safety. Available online: https:/ / minesafety.eu (accessed on 14 February 2021).

25. PN-EN ISO 9612:2011 Akustyka-Wyznaczanie Zawodowej Ekspozycji na Hałas-Metoda Techniczna.

26. PN-N-01307:1994 Hałas—Dopuszczalne Wartości Hałasu w Środowisku Pracy—Wymagania Dotyczące Wykonywania Pomiarów.

27. Rozporządzenie Ministra Gospodarki i Pracy z Dnia 5 Sierpnia 2005 r. w Sprawie Bezpieczeństwa i Higieny Pracy Przy Pracach Związanych z Narażeniem na Hałas lub Drgania Mechaniczne (Dz. U. 2005 nr 157 poz. 1318). Available online: http:/ / isap.sejm.gov.pl/isap.nsf/DocDetails.xsp?id=WDU20051571318 (accessed on 14 February 2021).

28. Rozporządzenie Ministra Pracy i Polityki Społecznej z Dnia 6 Czerwca 2014 r. w Sprawie Najwyższych Dopuszczalnych Stężeń i Natężeń Czynników Szkodliwych dla Zdrowia w Środowisku Pracy (Dz. U. 2014 poz. 817). Available online: https: / /isap.sejm.gov.pl/isap.nsf/DocDetails.xsp?id=WDU20140000817 (accessed on 14 February 2021).

29. PN-ISO 1999:2000 Wyznaczanie Ekspozycji Zawodowej na Hałas i Szacowanie Uszkodzenia Słuchu Wywołanego Hałasem.

30. Bołoz, Ł.; Biały, W. Automation and Robotization of Underground Mining in Poland. Appl. Sci. 2020, 10, 7221. [CrossRef] 